parallel to the long axis of the swelling, and obliquely inclined to its surface. The flap was seized with the iris forceps, and a tiny wedge-shaped piece was snipped off by the scissors. Firm pressure was then applied. I felt very doubtful of the capacity of the degenerated tissue for healing, and was delighted to find that the posterior edges of the wound had, in twenty-four hours, healed as readily as healthy cornea. The wound having completely cicatrised, though but little flattening had resulted, I again (May 28th) excised a wedge-shaped piece of tissue, about an eighth of an inch long and a line across at its widest part. This healed readily, and produced a marked improvement. On June $18 \mathrm{lh}$ I excised a third piece with like favourable result. When cicatrisation was complete the staphyloma was considerably flattened (though not quite level with the normal surface of the globe), and the lids closed easily and comfortably.

The main points conducive to success seem to be, that the posterior edges of the wound should be in apposition, and that a large piece of tissue be not removed at one sitting. As the operation is nearly painless, it might be repeated a dozen times if necessary.

2. Wound of an ocular muscle without injury to the globe is necessarily a rare and curious accident. The following is the only case I have ever seen.

J. K -, iron-roller, St. Helens, was hit by a flying fragment of metal between the lower lid and the globe, neither of which, strange to say, was injured. He applied at the infirmary some weeks after the accident on account of vertical diplopia. On inspection, an upward squint was manifest, and the power of downward movement was considerably impaired. At the bottom of the retro-tarsal fold was an irregular cicatrix, and the lower part of the ocular conjunctiva was red and much thickened. On June 11th I operated by snipping a free horizontal opening in the conjunctiva, about an eighth of an inch from the corneal margin. The tissues were matted together, but by careful employment of scissors and hook the attachments to the globe were freed; the tendon remaining joined to the conjunctiva. The superior rectus was now divided, and the lower tendon brought forward by three silk sutures, which were drawn sufficiently tight to give the eyeball a slight downward inclination. The wound healed readily; but when the superior rectus regained its power the improvement was found to be only partial, and I therefore (August 6th) brought the inferior rectus still further forward by a second operation, but did not again divide the superior tendon. 'The pupil was at first half its diameter lower than its fellow, but after the withdrawal of the sutures it gradually rose till it was level. The patient was discharged cured.

Liverpool.

\section{ON THE TREATMENT OF ALVEOLAR ABSCESS.}

BY ISIDOR I. LYONS, M.R.C.S., L.D.S.

ALVEOLAR abscess is the result of an acute inflammation of the periodental membrane. This may arise from various causes. It is commonly the sequel of acute inflammation of the pulp of a tooth, but it may commence in the membrane. An alveolar abscess generally points opposite to the buccal or labial surface of the affected tooth, or the pus may exude at its neck or travel along the hard palate and open at any point internal to the dental arch.

Among the different local remedies prescribed for this affection, the most common are external fomentations and poultices. This treatment is to be deplored for the following reason. When, for example, an abscess takes place at the root of an upper bicuspid tooth, and the swelling is at its buccal surface, on a poultice being applied externally, pus would travel above the fold of mucous membrane connecting the superior maxilla with the cheek, and appear among the buccal muscles, ultimately passing throngh the skin, thereby producing those ugly scars often seen on the face of patients who have undergone this treatment. The following cases are typical of these results.

Isabella $B-$, aged twenty-eight, admitted into St. Bartholomew's Hospital April 1st, 1875, under the care of Mr. Callender. This patient had suffered great pain for a long time from a carious lower molar, at the roots of which there had been an abscess. This had been treated by external fomentations and lancing of the gum. When admitted into the hospital, there was a soft red spot with two or three openings over the middle of the lower jaw, on the right side, extending behind towards the angle and ramus, and slightly down to the neck. There was also inability to open the mouth except to a very slight degree. The first lower molar was reduced to a stump. Since admission, the swelling behind and below has increased, and apparently suppuration taken place. On April 9th the right lower molar (which was necrosed) and the fangs of the two other teeth were extracted. On the 16th the abscess appeared to be discharging through openings in front of it. As regards the rest of the history of this patient, an attack of erysipelas supervened, involving both sides of the face, and which was remarkable for its severity and high temperature. On June 16th she was discharged, her general condition much improved.

Emily C-, aged twenty-four, admitted as an outpatient of the hospital April 8th, 1875, under the care of Mr. Coleman. This patient had acute periodontitis of the first left upper molar in the previous March, and was ordered to apply poultices externally. Within a week the abscess burst. In April she came to the hospital to have the tooth extracted. At that time the scar extended from that part of the cheek opposite the zygomatic arch to midway between it and the angle of the mouth.

G.S-, aged twenty-one, admitted as an out-patient on March 21st, 1875, under the care of Mr. Coleman. This patient had suffered from acute periodontitis of a left lower molar for one month; and, an abscess supervening, it was treated by external fomentations and poultices. At present there is a fistulous opening in the cheek.

The appropriate treatment in the above cases would, no doubt, be the immediate extraction of the offending teeth; but if desirous of saving them, by internal fomentations (the patient to be desired to bathe his mouth frequently with water at as warm a temperature as possible), also by lancing the gums and the application of leeches, and, when an abscess has formed, by free incisions.

The cases given are types of a very large number of outpatients seen at the dental department of the hospital.

\section{g. dituror}

\section{HOSPITAL PRACTICE, BRITISH AND FOREIGN.}

Nulla autem est alia pro certo noscendi via, nisi quamplurimas et morborum et dissectionum historias, tum aliorum, tum proprias collectas habere, $e$ inter se comparare.-Morgagri De Sed. et Caus. MLorb., lib. iv. Procmium

\section{ST. THOMAS'S HOSPITAL.}

OASE OF HYDROPHOBIA.

(Under the care of Mr. SYDNEY JoNas.)

A PoINT of interest in the following case, for the notes of which we are indebted to Mr. H. P. Potter, house-surgeon, was the benefit derived from the inhalation of chloroform. Although the case unfortunately proved fatal, the chloroform gave considerable relief.

Henry W-, aged twelve, a very healthy boy, rather hot-tempered but not nervous, applied at the hospital on September 24th, at 1 P.M., suffering from symptoms of bydrophobia. He had had no previous illness. The boy stated that six weeks ago, whilst stroking a dog which was chained, the animal snapped, and caught bold of his right little finger, and he had to pull it forcibly out of its mouth. No one else was bitten. The dog was killed two days after, and was said to be suffering from rabies. The finger was simply bound up in rag for two days, when he came to the hospital, and poultices were ordered. The wound healed in about a fortnight. During the interval the boy was pretty well, but sometimes he was rather strange in his manner; never spoke of fear of hydrophobia. On the evening of the 19th September he was taken with rigors, and complained 